\title{
STUDENTS' AND TEACHERS' PERSPECTIVES ON EFL TEXTBOOK FOR SENIOR HIGH SCHOOL STUDENTS
}

\author{
Lina Herlina ${ }^{1}$, Soenarjati Djajanegara ${ }^{2}$, Mamik Suendarti ${ }^{3}$ \\ English Education Graduate Program, Universitas Indraprasta PGRI \\ 'linasmaim@gmail.com
}

\begin{abstract}
Abstrak
Tujuan penelitian ini adalah untuk mengevaluasi efektivitas buku teks bahasa Inggris berjudul "Bahasa Inggris SMA/MA/SMK/MAK Kelas X" dari perspektif siswa dan guru. Buku pelajaran ini disiapkan oleh Kementerian Pendidikan Nasional Indonesia untuk siswa kelas 10 dan digunakan oleh beberapa guru selama tahun akademik 2018-2019. Evaluasi terhadap buku pelajaran ini dilakukan di tingkat makro berdasarkan sebelas kriteria. Data diperoleh melalui angket siswa yang diberikan kepada 94 siswa dan wawancara dengan 4 guru. Data tersebut dianalisis dan dikelompokkan berdasarkan 11 kriteria yang digunakan dalam penelitian ini untuk evaluasi buku pelajaran tertentu. Hasil penelitian menunjukkan mayoritas siswa menyebutkan bahwa tingkat buku teks tidak sesuai untuk kelompok umur mereka. Para guru menunjukkan bahwa tugas dan kegiatan tidak diatur dari tahap mudah ke sulit. Ini juga menunjukkan bahwa kegiatan mendengarkan tidak didukung oleh rekaman audio yang seharusnya disertakan dalam buku teks. Selain itu, para siswa berharap adanya latihan dalam bentuk pilihan ganda. Ini menyiratkan bahwa beberapa aspek dari buku teks perlu direvisi dan rekaman audio harus dimasukkan untuk mendukung kegiatan mendengarkan. Di sisi lain, salah satu kelebihan dari buku pelajaran ini adalah bahwa kegiatan dalam buku pelajaran ini melibatkan peluang yang mendorong kreativitas, minat, dan keingintahuan siswa.
\end{abstract}

Kata Kunci: buku pelajaran Bahasa Inggris, evaluasi buku teks, evaluasi makro

\begin{abstract}
)
The purpose of this study is to evaluate the effectiveness of an English textbook "Bahasa Inggris $S M A / M A / S M K / M A K$ Kelas $X$ ” from the perspectives of students and teachers. The textbook was prepared by the Indonesian Ministry of National Education for the 10th-grade students and used by some teachers during the 2018-2019 academic year. The evaluation of the concern for the textbook is carried out at the macro level based on eleven parameters. Data was obtained through student questionnaires administered to 94 students and through interviews with four teachers. The data were analyzed and grouped according to 11 criteria used in this study for the evaluation of the particular textbook. The results showed that the majority of students indicated that the level of the textbook was not appropriate for the particular age group. The teachers pointed out that the tasks and activities were not organized from easy to difficult stages. Also, the listening activities were not supported by audio recordings that should have been included in the textbook. Moreover, the students expected the book to include multiple-choice exercises. It implies that some aspects of the textbook need to be revised, and the audio recordings must be included to support the listening activities. On the other hand, one of the strengths of the textbook was that the activities in the textbook involved opportunities that encourage students' creativity, interest, and curiosity.
\end{abstract}

Keywords: EFL textbook, textbook evaluation, macro evaluation 


\section{INTRODUCTION}

Teaching and learning resources include textbooks or coursebooks that play a crucial role. Andon (2018) recalls that "Materials are at the very center of language teaching, and understanding what goes into creating them is an essential part of a language teacher's professional development." For many professionals, English Language Teaching (ELT) textbooks are the essential elements of English as a Foreign Language (ELF) teaching and are currently the most widely used teaching materials in schools. In describing the vital role of textbooks in ELF teaching, Benevento (Benevento, 1984) states that every time foreign language teachers meet, the first words after "How do you do it?" Often, "what coursebooks do you use?".

Furthermore, Baker, Dubin \& Olshtain (Baker et al., 1989) noted that the textbook is the concrete component that provides most learners and teachers with a language course. With regard to the primary purpose of the ELT textbooks, Byrd \& Schuemann (Khoo \& Knight, 2015) state that ELT textbooks incorporate two types of information, thematic/topic material (family, school, etc.) and linguistic material (grammar, vocabulary, and competencies). ELT textbook users interact with the document's content to learn the language skills required to communicate in a foreign language. ELT textbooks improve their four competencies, i.e. listening, speaking, learning, and writing in a second or foreign language. In other words, many ELT textbooks ' primary purpose is to help learners understand the linguistic content extensively through the use of thematic content. Bryd \& Schuemann's concept is then confirmed these days when Khoo \& Knight (Khoo \& Knight, 2015) seek to examine the relevance of existing textbooks to the needs of students and the need for public examinations. Their study shows that Even with some limitations, the textbooks were found to be highly appropriate in laying the groundwork for the two talking and writing skills.

It should be recalled that the language itself is taught and studied only through the use of textbooks. Many teachers start a school without a textbook that offers material and instructional exercises that make up a lot of what is learned in the classroom. Since it is at the heart of the language teaching/learning process, textbooks are defined by several specialists through a variety of resources. For example, Tomlinson (Tomlinson, 2011) uses the term "coursebook" instead of "textbook" and states that a textbook is a textbook that provides necessary materials for a course and serves as the only book that learners use during a course. It usually includes work on grammar, vocabulary, pronunciation, functions, and four skills (p. 9). Hutchinson and Torres (Hutchinson \& Torres, 1994) described the textbook as an essential means of meeting the range of needs that emerge from the classroom and its broader context (p. 327).

Concerning the role of ELT textbooks in the language teaching and learning system, many English language teaching practitioners hold a wide range of views on the use and usefulness of ELT textbooks in classrooms. According to Tomlinson (Tomlinson, 2011, 2012), some people are against ELT textbooks because, in terms of content and implementation, they are constrained in meeting students ' needs. On the other hand, some people are more optimistic about using ELT textbooks as textbooks provide the learning process with a framework and continuity for them. The textbook has a critical and constructive role to play in teaching and learning English in the daily work of teachers and students. Besides, textbooks have become a fundamental feature of ELT teaching (Hutchinson and Torres, 1994; Tomlinson, 2011, 2012).

Both teachers and learners certainly recognize the importance and role of the textbook in the teaching-learning process. In other words, there seems to be a consensus 
among teachers and students concerning the primary role of the textbooks. To illustrate, Hutchinson and Torres (1994) refer to one of the author's studies in which teachers and students were asked why they wanted to use a published textbook. The result showed that learners saw the textbook as a framework or guide that helps them to organize their learning both outside and inside the classroom during discussions in lessons while doing activities and exercises, doing homework and preparing for tests. A textbook enables them to learn better, faster, clearer, more comfortable and more (p. 318). In other words, in this long-lasting learning process, ELT textbooks help learners find their way. As far as teachers are concerned, the results show that many teachers see the textbook as a method for handling the relationship between them and their students.

Since textbooks are perceived as a vital and vital element in teaching and learning English by both teachers and students, textbooks in general and ELT textbooks, in particular, should meet specific standards and criteria. Tomlinson (1998) points out that materials should raise their curiosity, interest, and attention in order to affect ESOL learners. One way to do this can be through an attractive presentation. The examples he gives are attractive colors, the use of photographs, and exciting themes. He also recommends that learners feel at ease with the materials they use and adds that making ESOL learners feel at ease can be achieved through careful design. Learners feel more comfortable with materials, including much white space than with materials with a lot of different activities on the same page. Also, materials should allow learners to build confidence in their language skills and themselves as language learners. He argues that building trust can be achieved through activities that try to push learners and make them aware of their learning (Tomlinson, 1998). Cunningsworth (1995) highlights the difficulty of choosing appropriate language teaching textbooks and materials. He states that since there is a great variety of published materials for English language teaching available on the market, it becomes a challenging task to make the right choice of the textbooks. Besides, learners are becoming worldly-wise due to the impact of high technology. Therefore, they expect better textbooks that make learning more accessible and enjoyable, and that appeals to their interests and needs all the way around.

In this context, in order to select an effective and appropriate textbook, materials evaluation becomes an unavoidable process with defined guidelines and criteria. Researchers have developed some reference checklists that could be used in material evaluation in general and textbook evaluation in particular. For example, Cunningsworth (1995) provides a quick reference checklist for evaluation and selection of ELT textbooks. Similarly, Skierso (1991) recommends an evaluation checklist, which covers areas such as aims and goals, subject matter, exercises grammar, vocabulary, teacher's manual. Supadi (2015) and Zohrabi (2011) also mention the importance of selecting suitable coursebook for EFL students of vocational schools as well as of general courses. Since the primary users of textbooks are the instructors and the learners, evaluation should be carried out while both parties are using the textbook to get their opinions about how the textbook works in the teaching-learning situation. To conclude, it is a fact that the evaluation of the textbook and other materials is the natural and essential part of the implementation of a textbook in any institution. Despite the vital role that textbooks play in teaching and learning English as a foreign language in Indonesia, there is limited research conducted to evaluate textbooks. 


\section{RESEARCH METHOD}

Survey and interview techniques were used in this research. Students were presented with a self-administered questionnaire in which they were asked to answer questions related to the characteristics of the textbook they studied.

\section{Respondents}

The sample of this survey study was of 10th-grade students and teachers from four public senior high schools in Sukabumi West Java. They are SMAN 1 Cibadak, SMAN 1 Parungkuda, SMAN 1 Cicurug, and SMAN 1, Cikembar. The students learned English for every two hours a week. Their age ranged from age 15 to 17 years old, consisted of 59 female students and 35 male students. One English language teacher who used the textbook in his/her classes was selected from each school. One of the four teachers was male, and the others were females with various teaching experiences ranged from 11 to 19 years.

\section{Questionnaire}

Based on responses students and the related literature, the statements were presented in the form of items for subjects to endorse on a five-point Likert-type scale from "Strongly Disagree" to "Strongly Agree." Two specialists from Universitas Indraprasta PGRI examined the questionnaire. This review helped to eliminate the ambiguities, to complete lacking topics and issues, and to examine the face validity. The face validity also examined by reviewing the literature.

The questionnaire was composed of two sections. The first section requested background information, such as the name of the school, English course grade, age, and gender. The second section of the questionnaire consisted of 62 items related to ten criteria determined through literature review (see. Introduction) to conduct a macro-level material evaluation. The questionnaires were administered to students either by their teachers of English or by the researcher during the class time. Teachers were interviewed by the researcher using the interview schedule. The interviews were conducted with four teachers between 6th May and 10th May 2019. The individual recorded interviews took approximately 30 minutes. The criteria and the matching questionnaire items were given as follows:

1. Selection and Organization of Content: In this part, there were $3(1,2,3)$ items that questioned the organization of the materials and the units within the textbook.

2. Level: This section consisted of 5 items $(4,5,6,7,8)$ that focused on the appropriateness of the level of the textbook and related activities for the particular learners.

3. Physical Appearances: This section includes ten items $(9,10,11,12,13,14,15,16,17,18)$, which focused on the use of pictures, illustrations, durability, the layout, and the general outlook of the textbook.

4. Content: This section consisted of thirteen items $(19,20,21,22,23,24,25,27,28,29,30,31)$ which focused on the suitability of content in the textbook in relation to the variety and interest level of topics/themes.

5. Exercises and Activities: This section consisted of twelve items $(32,33,34,35,36,37,38,39,40,41,42,43)$, which focused on the appropriateness of the level of the exercises and activities for the particular group. It also investigated a variety of activities and whether they aimed to improve the four language skills.

6. Vocabulary and Grammar: This section consisted of four items $(44,45,46,47)$, which focused on the effectiveness and amount of vocabulary activities and the presentation of the grammar. 
7. Clarity of Instructions: This section consisted of only one item (48) that investigated whether the instructions in the textbook were clear to understand.

8. Supporting Sources: This section included five items $(49,50,51,52,53)$ that questioned to what extent the supporting sources help students revise and practice new vocabulary, grammar, and skills.

9. Development of Learner Autonomy: This section involved six items $(55,56,57,58,59)$ that investigated the extent to which learner training elements were incorporated into the materials in order to develop learner autonomy.

10. Consideration of Learning Style Differences: This section consisted of three items $(60,61,62)$ that investigated to what extent the textbook considered the visual, auditory, and kinesthetic learner preferences in terms of the activities and exercises.

\section{Interview Schedule}

The interview was used to collect the information related to perceptions of teachers on the effectiveness of the textbook they used. Another aim was to get their suggestions for improving the textbook. The researcher prepared an interview guide comprising the 17 open-ended questions related to ten criteria mentioned above. The other questions in the interview schedule were related to the effectiveness of the textbook in the attainment of the desired goals and objectives as perceived by the teachers and their suggestions about the improvement of the textbook. The effectiveness of the teachers' book as the last research question was evaluated through the interviews.

\section{RESULT AND DISCUSSION}

This section displays the results and discussion together based on the 11 parameters mentioned earlier in the introduction section.

\section{Selection and Organization of Content}

The results of analyses revealed that the textbook was not very useful in terms of selection and organization of content features. Although both students and teachers felt positive about the integration of writing, listening, and speaking activities coming after the reading passages, teachers, on the other hand, highlighted that the tasks and activities were not organized in a clear and logical sequence.

However, the students felt in the middle about the tasks and activities moving from simple to complex. This might imply that the students might not very much aware of the organization and grading of the materials. This reveals the necessity of informing and orienting the students about the organization and linkage of the materials in the textbook. The learners should know that the skills, tasks, and activities are graded in terms of difficulty throughout the textbook. Breen and Candlin (1987) point out that the selection and organization of content in the materials is quite remarkable. They stressed that the organization of the materials should be done in such a way that learners can work on them and internalize the content. Materials should be organized for familiar and straightforward 'thing' to more complex and 'less familiar.' Breen and Candlin (1987) also mentioned the importance of continuity in the materials. They indicate that after the determination of the content, it is divided up, logically sequenced, and finally provided with particular continuity.

On the other hand, students indicated that reading passages in the units and listening, writing, and speaking activities coming afterward were presented in an integrated way. It should be noted that the students seemed aware of the fact that integration of reading into other skills may contribute to the reinforcement of what has 
been learned and practiced. As it is stated in the literature, integration of skills is essential in a sense that it can enable students to gain a deeper understanding of how communication works in the foreign languages as well as becoming more motivated when they see the value of performing tasks and activities in the class (McDonough and Shaw, 1993). Grant (1987) and McDonough and Shaw (1993) included items relating to the organization, sequencing, linkage, and continuity of the materials or units in a textbook.

\section{Level}

Results indicated that the students' perceptions about the level of the textbook were much more harmful than the teachers' perceptions. The qualitative data indicated that most teachers perceived the textbook suits the level of the students. On the other hand, both teachers and students felt positive about the level of writing and speaking activities in the textbook. However, the results revealed that some of the students perceived the listening activities in the textbook as quite difficult for them. This might be since the listening activities in the particular textbook were skipped because of the unavailability of the audio recordings. Therefore, the students might have thought that the listening activities were challenging for them to cope with.

As stated by Cunningsworth (1995), it should be checked whether the coursebook deals appropriately with all four skills, considering the level. He also adds that there should be a suitable balance between skills and indicates that the reading passages and associated activities should be suitable for the language level of the students. The findings related to the level of the textbook of this study revealed that students were more likely to agree that the level of the particular textbook was not appropriate for the level of 10thgrade students. However, the appropriateness of the level of materials to the language level of students is one of the most mentioned criteria in evaluating a textbook or a teaching material by researchers (Cunningsworth, 1995; Grant, 1987; Mukundan et al., 2011; Sheldon, 1988).

\section{Physical appearance}

The results revealed that both instructors' and students' perceptions about the physical appearance of the textbook seemed to be positive in terms of type, font size, durability, artwork, and colors used. Besides, both groups agreed that the artwork in the textbook was up to date. They also seemed happy because this helped the students to understand the lessons well. Similarly, both teachers and students were also positive about other aspects related to physical appearance. That is, both groups agreed about the attractiveness of the cover and the layout. Students and teachers also felt very positive about the motivating effect of the layout on the performance of tasks. The interview results revealed that the teachers had no specific complaints related to the layout in the textbook.

In the literature, the physical appearance of a textbook regarded as very important. All of the authors mention the physical attractiveness of the materials and textbooks to motivate the students and to encourage them to take part in the teaching/learning process, Griffiths (1995) points out that interesting, attractive, colorful, and well-illustrated materials are more favorable for learners. Moreover, McDonough and Shaw (1993) also indicate clarity of layout and visuals such as tables, charts, and diagrams as the two crucial criteria for textbook evaluation. Similarly, Skierso (1991) also proposes criteria for the evaluation of the physical appearance of the materials about such aspects as motivational attractiveness, organizational clarity and function, effectiveness in presentation, 
relativity, linkage and integration, practical and explicit use of artwork, illustrative clarity simplicity and motivational atmosphere created within the language teaching materials. All these imply that appropriate layout and physical make-up contribute a lot to student learning and motivation. At this stage, it is possible to say that "Bahasa Inggris SMA/MA/SMK/MAK Kelas X" has achieved to create a positive feeling on the students, which can be considered as a success in terms of the motivational attractiveness of the layout and the cover of the textbook.

\section{Content}

The results revealed that both teachers and students felt positive about the textbook in terms of 'content.' First of all, a vast majority of students, as well as teachers, perceived the topics of the units in "Bahasa Inggris SMA/MA/SMK/MAK Kelas X" interesting. Also, the students perceived the topics as up-to-date related to their daily lives. Similar to the students, the teachers perceived the topics in a particular textbook engaging. However, teachers mentioned that even though the titles of the reading passages seemed to be exciting and up to date, the lengthy passages filled with a significant load of unfamiliar vocabulary and complex sentence structures did not appeal to the students' interest. One conclusion that can be drawn from this is that regardless of the titles being exciting or when the reading texts in the units are lengthy and involve many unfamiliar words and complicated sentence structures, it fails for the students to cope with the reading sections.

These findings also indicated that the topics facilitated the improvement of speaking skills in the classroom. The students believed that the topics of the units encouraged them to communicate in the target language with each other. Cunningsworth (1995) states, a communicative textbook promotes meaningful communication among its users through relevant and exciting topics. Tomlinson (1998) also points out that learners should be given opportunities to use the target language to fulfill communicative purposes. This above finding verifies the results about the sufficiency of coverage of four skills, namely reading, listening, writing, and speaking in a particular textbook. McDonough and Shaw (1993) indicate that skill development is essential and material developers should provide the students with sufficient opportunity to develop those skills through adequate practice.

The results also revealed that Fun Corner sections in the "Bahasa Inggris SMA/MA/SMK/MAK Kelas X" were perceived instructive and enjoyable. Each unit in the particular textbook consists of "fun corner" parts in which there are funny jokes. However, both teachers and students expressed a great desire for more fun in their textbook. Moreover, both parties, especially students, pointed out that the particular textbook should involve some popular songs, multiple-choice exercises, biographies of famous people, topics such as health, sport, habits, which would provide them with some knowledge. They believed that these would facilitate learning English. It can be drawn these results that students and teachers are in search of some additional materials that could appeal to their needs and interests. Textbook content is considered to be an important element in the literature by many authors in the evaluation and design of language coursebooks. (Cunningsworth, 1995; Hutchinson \& Torres, 1994; Mukundan et al., 2011; Sheldon, 1988; Tomlinson, 2011, 2012). 


\section{Exercises and Activities}

The quantitative and qualitative data analyses indicated that both the students' and teachers' perceptions about the activities and exercises of the textbook were positive in general. Both teachers and students believed that exercises and activities were enjoyable. Similarly, both teachers and students stated that the activities and exercises in the textbook helped to increase the students' desire to learn English. Moreover, increase the students' participation in the lesson. These results are in line to Cunningworth (1995) who states that the authors should check if the reading passages are of real interest and need of the learner as authentic as possible considering the level, well-presented, and purposeful activities that help the learning process.

It can be concluded that "Bahasa Inggris SMA/MA/SMK/MAK Kelas X" provided the particular group of learners with efficient reading exercises and activities that are appropriate to their needs and interests, language level and that aim to improve their reading skills. As for the writing skills, the results revealed that both teachers' and students' opinions about the writing activities were positive. Teachers especially believed that the writing activities and exercises in the textbook helped to improve their writing skills.

On the other hand, neither the students nor the teachers seemed to be happy about the effectiveness of the listening activities and exercises in improving speaking and listening skills. Both teachers and students agreed that the listening activities and exercises in the textbook did not encourage the students to use English both inside and outside the classroom. Teachers stated that this might be due to the unavailability of the audio recordings to support the activities. As for the listening exercises and activities, it was found that the textbook was not adequate to improve students' listening skills. The analyses indicated that the listening recorded materials had to be provided; otherwise, the students would not be motivated enough do accomplish the listening activities and exercises. The results also revealed that in most classes, the listening parts in the textbook were skipped off due to this issue. Both teachers and students complained a lot about this situation. Literature indicated that 'exercises and activities' involved in the textbooks are among the primary aspects of the textbooks that need to be evaluated. Many authors like Grant (1987) and Sheldon (1987) all included items related to exercises and activities in the textbooks in their criteria and checklists. They emphasized the sufficiency, variety, and adequacy of the activities

\section{Vocabulary and Grammar}

The results of the analyses revealed that the vocabulary and grammar presentation sections of the textbook were positively commented on. However, there was one striking finding of this study, that the reading passages included too many vocabulary items. Teachers in the interviews emphasized that due to the vocabulary load in the reading passages, the students had great difficulty in comprehending the reading texts and doing the related tasks and activities. Hinkel (2006) emphasized that a word should be encountered 12-20 times in order to be learned from a context. This further implies that textbook writers need to check that new items are recycled appropriately in the course.

The results revealed that the particular textbook was not useful in the presentation of grammar. The teachers stated that the grammar sections in the textbook should be presented in more detail. The teachers pointed out that they had to use supplementary materials at the presentation and practice stages of grammar teaching. It can be noted that the particular textbook does not provide the students and teachers with a sufficient number 
and variety of grammar exercises. It is stated in the literature that 'grammar' is considered to be one of the essential parts of any language course. Cunningsworth (1995) points out that the first considerations of textbook writes are what grammar items to include and to what extent they will correspond to learner needs. He believes that with the effective teaching of grammar, learners are equipped with the ability to make their sentences and will be able to use the target language for their purposes. Therefore, it can be drawn that textbook writers should guarantee that language teaching materials involve clear, compelling and complete grammar presentations so that students can have a good practice and concise review. Besides, they should make sure that teachers are provided with sufficient and various grammar supplementary materials. Consequently, from the results of the study concerning the particular aspect of the materials, it can be concluded that both teachers' perceptions about vocabulary and grammar were not much positive. Thus, it reveals that "Bahasa Inggris SMA/MA/SMK/MAK Kelas X" is not sufficient enough in terms of the practice of vocabulary and presentation of grammar.

\section{Clarity of instructions}

The results revealed that the students' and teachers' perceptions about the clarity of instructions in the textbook seemed to be different. The quantitative data revealed that students were very sure about the clarity of instructions. However, teachers emphasized in the interviews that although most activities/tasks did not require the teacher to give further explanation, their students continued to ask for the clarification and confirmation of their teacher whether they have understood the instruction correctly or not. Two conclusions can be drawn from these results. First, students want to ensure that they have understood the instruction correctly and avoid any misunderstandings. This might be since language learners, especially the weak ones, have a fear of making a mistake while doing the tests and want to be sure that they understood the instructions correctly. This is a frequently observed incidence in language classes. Second, this may be because the students are very much used to getting instructions from the teacher.

It is evident from the results that clarity of instruction is another aspect of language teaching materials that need to be examined because it helps to facilitate learning and spend time on the activities themselves rather than understanding how they should be coped with or what should be done. It should be stated that clarity of instructions is, in fact, critical to any language teaching materials. In other words, it is an important aspect that can be applied to any teaching materials. Thus, as Tomlinson (1999) points out, it is one of the 'universal criteria,' which applies to any specific unit of materials. Jolly and Bolitho (Tomlinson, 2011) indicate that part of an adequate pedagogical understanding of materials is effective and efficient writing of instruction, including the proper use of meta-language. They also state that one of the most essential tasks of the materials writers should be to provide clear instructions to the activities and exercises which will meet the need for language -learning work. Poor instructions for use are believed to be able to waste a lot of valuable students. Consequently, clarity of instructions is also recognized as one of the most common criteria in the various checklists and suggested guidelines.

\section{Supporting Sources}

The results of the supporting sources of the textbook indicated that both teachers and students felt positive about the consolidation parts of the textbook. They thought that those parts provided the students with useful practice. Teachers indicated that the consolidation parts of the textbook provided a sufficient number of exercises to review 
the book as well. However, they also stated that it served as an extra workload in terms of grammar and vocabulary learned in the class. Similarly, although the teachers reported that the workbook provided effective reinforcement for the grammar structures and vocabulary presented in the textbook, they also stated that they could not use the workbook effectively on regular bases because of the time allocated for the course. The conclusion that can be drawn this is that pacing seems to impede the exploitation of the workbook concerned, although it is considered to be a beneficial supplementary material for the retention of what has introduced in the textbook.

\section{Development of learner autonomy}

The results indicated that both students and teachers perceived the reading activities and exercises in the textbook as conductive in learner autonomy; that is, they involved opportunities that encouraged creativity, interest, and curiosity. They also thought that those reading texts and activities helped the students gain different points of view. Similarly, the reading passages and the related activities appealed to students' interests and fostered creativity and curiosity as well. Also, the reading passages and activities helped the students to gain different points of view. Moreover, both students and teachers agreed that the activities in the textbook helped them evaluate what they had learned. Thus, this is parallel to the fact that the textbooks should enable learners to judge how well they performed, which requires learners to monitor their progress.

Both students and teachers agreed that the textbook allowed learners to be more aware of their strengths and weaknesses while developing the four language skills (reading, writing listening, and speaking). At this stage, these findings are consistent with the fact that it is vital to inform learners about the skills and strategies applicable for different learning contexts and evaluation of strategies, which enables learners to be aware of what they are doing and why they are doing it (Sinclair and Ellis, 1992). Consequently, the results reveal that "Bahasa Inggris SMA/MA/SMK/MAK Kelas X" is useful in raising awareness on how to employ various language learning strategies, skills, and techniques. Besides, the students may be well aware of the importance of learner autonomy in language teaching materials.

\section{Consideration of learning styles differences}

The results revealed that the students' and the teachers' perceptions about the criterion "consideration of different learning styles" were the same in general. Both students and teachers agreed that "Bahasa Inggris SMA/MA/SMK/MAK Kelas X" included a sufficient number of visuals to some extent. However, it should also be noted that they still demand some more visuals to be included in the textbook. This would accompany the activities and support learning.

The overall results of the items with the listening sections revealed that the vast majority of the students had positive attitudes toward those sections. On the other hand, the teachers stated that such sections failed to enable the students to learn through listening due to the absence of the audio recording. They had to provide it by themselves, so it enabled students to learn through listening.

Furthermore, the students agreed that the particular textbook provided enough opportunities for the students to learn by being physically involved in the activities. It is parallel with the fact that the activities should reflect a concern for learning styles differences so that the materials can address the needs, interests, and expectations of visual, auditory, and kinesthetic learners. 
Thus, the critical point for the materials developers is that they should be aware of and cater for differences in preferred learning styles in their materials. They should not assume that all learners benefit from the same approaches either. Learners should be provided with a variety of activities addressing different learning styles, which, in turn, will provide opportunities for a variety of strengths and, as a result, learners will not be restricted to a single style of thinking or learning.

\section{Teachers' Book}

The qualitative data analyses revealed that the teachers' perceptions about the particular criterion were negative. Even though all of the teachers stated that they did not find any difficulties in using it, one of the teachers expressed that the book was quite dull. Two of the teachers stated that they only used the teacher's book to have an idea about the warm-up stages. They all complained that the teacher's book did not help them with each new type of lesson introduced.

They added that they sometimes needed some background information about a new topic. Besides, they all complained that the particular teacher's book did not provide practical activities/ideas for the teachers to use in the class either. All the teachers indicated that the teacher's book could have included some games, activities involving some fun and popular songs to be used through the end of the lessons. They stated that such extra materials save the lessons from monotony. The teachers were asked if the teacher's book advised on a variety of lesson presentation techniques. They all stated that they were not provided with such advice. However, they all added that it could have been beneficial if the teacher's book gave some advice on different techniques.

The conclusion that can be drawn from these results is that all the teachers are well aware of the significance of the teacher's book in the process of teaching a language. Regardless of their teaching experience, those teachers still seek guidance on what to do and how to do it. As Cunningsworth (1995) points out, a good teacher's book is invaluable in the offering, among other things, guidelines on how to make the best use of the course. (p.112)

\section{CONCLUSION}

The selection and organization of the content of the textbook were not very useful due to the task and the activities which were not organized in a clear and logical sequence. The textbook was not appropriate for the level of $10^{\text {th }}$-grade students, and it was not practical enough in terms of the practice of vocabulary and presentation of grammar. Although the physical appearance of the textbook was attractive, which can be considered as a success in terms of the motivational attractiveness of the layout and the cover of the textbook. In terms of the content, it was found effective in attracting the students' interest, but there were too many unfamiliar words in the passages. On the other hand, the exercises and activities in the textbook were functional in general, except for the listening section. The clarity of instruction of the textbook needed an improvement, yet the supporting sources of the textbook were active that they provided students with useful practice. Alternatively, the textbook was useful to the development of learner's autonomy and was enough according to the consideration of learning style differences. The teacher's manual can be improved, so that it helps the teachers to improve their creativity in teaching. 


\section{REFERENCES}

Andon, N. (2018). Materials development for tesol. ELT Journal, 72(1), 112-113. https://doi.org/10.1093/elt/ccx062

Baker, W. D., Dubin, F., \& Olshtain, E. (1989). Course design: Developing programs and materials for language learning. Hispania, 72(1), 158. https://doi.org/10.2307/342695

Benevento, J. (1984). Choosing and using textbooks. Annual Meeting of the American Council on the Teaching of Foreign Languages.

Cunningsworth, A. (1995). Choosing your coursebook. Oxford: Heinemann.

Grant, N. (1987). Making the most of your textbook. Longman. https://books.google.ca/books?id=pM14AAAAIAAJ

Hutchinson, T., \& Torres, E. (1994). The textbook as agent of change. ELT Journal, 48, 4. http://citeseerx.ist.psu.edu/viewdoc/download?doi=10.1.1.476.1187\&rep= rep1 \& type=pdf

Khoo, H. S., \& Knight, P. (2015). Teachers' evaluation of KBSM Form 4, 5 English textbooks used in the secondary schools in Penang, Malaysia. Advances in Language and Literary Studies, 6(4), 128-150.

Mukundan, J., Hajimohammadi, R., \& Nimehchisalem, V. (2011). Developing an English language textbook evaluation checklist. Contemporary Issues in Education Research, 4(6), 21-28.

Sheldon, L. E. (1988). Evaluating ELT textbooks and materials. ELT Journal, 42(4), 237246.

Skierso, A. (1991). Textbook selection and evaluation. In M. C. Murcia (Ed.), Teaching English as a second or foreign language (pp. 432-453). Heinle and Heinle Publishers.

Supadi, S. (2015). Criteria in selecting English textbooks fo SMK students. DEIKSIS, 3(04), 324-338. https://doi.org/http://dx.doi.org/10.30998/deiksis.v3i04.438

Tomlinson, B. (2011). Introduction: principles and procedures of materials development. In Materials Development in Language Teaching.

Tomlinson, B. (2012). Materials development for language learning and teaching. Language Teaching, 45(2), 143-179. https://doi.org/10.1017/S0261444811000528

Zohrabi, M. (2011). Coursebook development and evaluation for English for general purposes course. English Language Teaching, 4(2), 213. https://doi.org/10.5539/elt.v4n2p 